\title{
Hydrologic modelling using TRMM-based rainfall products for flood analysis
}

\author{
Sigit Sutikno ${ }^{1, *}$, Yohanna Lilis Handayani ${ }^{1}$, Manyuk Fauzi $^{1}$, Fitriani ${ }^{1}$, Ariani Kurnia $^{1}$, and Rinaldi $^{1}$ \\ ${ }^{1}$ Civil Engineering Department, University of Riau, 28293 Pekanbaru, Indonesia
}

\begin{abstract}
The low resolution and the limitation of data are the main problems for flood analysis, so that the flood prediction often becomes inaccurate. This led to the decision policy for flood disaster mitigation often becomes ineffective. Currently the available of satellite-estimated rainfall data is gradually becoming a cost-effective source of input for flood prediction under a variety of circumstances. This study developed a hydrologic modelling using Tropical Rainfall Measuring Mission (TRMM) satellites data and IFAS (Integrated Flood Analysis System) tool for flood analysis. Upper Rokan watershed with the AWLR (Automatic Water Level Recorder) station of Lubuk Bendahara and Pasir Pangaraian in Riau Province were picked up as study area of this research. The study areas are located in Rokan Hulu regency which is the most vulnerable regency against flood disaster in Riau Province. The results show that the hydrologic modelling using satellite data can be used as an alternative for flood analysis in the area with limited ground data. The flood discharge prediction shows an acceptable error with the ground measurement data. The wave shape error, the volume error, and the peak discharge error for Lubuk Bendahara station are 9.58\%, $17.28 \%$, and $10.81 \%$, and for Pasir Pangaraian station are $33.62 \%, 8.60 \%$ and $5.88 \%$ respectively.
\end{abstract}

\section{Introduction}

Floods are among the most recurring and devastating natural hazards, impacting human lives and causing severe economic damage throughout the world. It is understood that flood risks will not subside in the future, and with the onset of climate change, flood intensity and frequency will threaten many regions of the world [1]. The main problem for flood analysis in Indonesia and other developing country is the low resolution and the limitation of data, so that the flood prediction often become inaccurate $[2,3]$. This led to the decision policy for flood disaster mitigation often becomes ineffective.

Currently the available of satellite-estimated rainfall data is gradually becoming a cost-effective source of input for flood prediction under a variety of circumstances. One such satellite rainfall product, the National Aeronautics and Space Administration (NASA) Tropical Rainfall Measuring Mission (TRMM) has been used extensively and provides quasi global $\left(50^{\circ} \mathrm{S}-50^{\circ} \mathrm{N}\right)$ precipitation analyses at 3-hourly, $0.25^{\circ}$ latitudelongitude resolution, with all satellite estimates calibrated or adjusted to the information from the TRMM satellite itself, which carries both a radar and passive microwave sensor $[4,5]$.

This study developed a hydrologic modeling using TRMM satellites data and IFAS (Integrated Flood Analysis System) tool for flood analysis. IFAS was developed by Hydrologic Engineering Research team, International Centre for Water Hazard and Risk Management (ICHARM), Japan. The application of
IFAS which includes interface for utilisation of satellitebased rainfall as the input is suitable for the catchment in developing country which the availability of ground rainfall stations is limited. The design concept in developing the flood analysis model are the software can utilize both satellite and ground-based rainfall as an input; implementation of runoff analysis engine; implementation of a model creation and a parameter estimation function; visualisation of flood result and free distribution [3, 6-8].

Upper Rokan watershed with the AWLR (Automatic Water Level Recorder) station of Lubuk Bendahara and Pasir Pangaraian in Riau Province were picked up as study area of this research. The study areas are located in Rokan Hulu regency which is the most vulnerable regency against flood disaster in Riau Province. The applicability of the IFAS in Indonesia has been studied in some cases [9-11]. However, those study were still limited for low flow hydrologic analysis. The applicability of IFAS for flood analysis also have been used in wide range around the word [12]. The applicability of IFAS for high flow analysis in case of flood in upper Rokan watershed, Indonesia was further evaluated in this study.

\section{Methods}

\subsection{Study area}

This study is focused in the Upper Rokan watershed with the AWLR station of Lubuk Bendahara and Pasir

\footnotetext{
* Corresponding author: ssutiknoyk@yahoo.com
} 
Pangaraian in Riau Province as shown in Fig. 1. Lubuk Bendahara and Pasir Pangarayan Sub-watershed have catchment area about $3,196 \mathrm{~km}^{2}$ and $1,595 \mathrm{~km}^{2}$ respectively. The topography of study area is quite varied ranging from 100 meters to over 1,000 meters above sea level, which is about $80 \%$ of its altitude in range between 100 and 500 meters. The upper Rokan watershed generally is a tropical climate with an average maximum temperature of $31^{\circ} \mathrm{C}-32^{\circ} \mathrm{C}$. The climate is strongly influenced by changes in wind direction, which the rainy season usually fall on October to April.

Rokan Hulu regency wich is located in upper Rokan watershed had experienced flood diaster almost every year since 2002 . The most severe damage was occured in 2014. It was reported that 69 villages in 13 sub-districts in Rokan Hulu regency was inundated by the flood, 18 people were killed, 17,816 houses were damaged, and 53,725 people were evacuated [13].

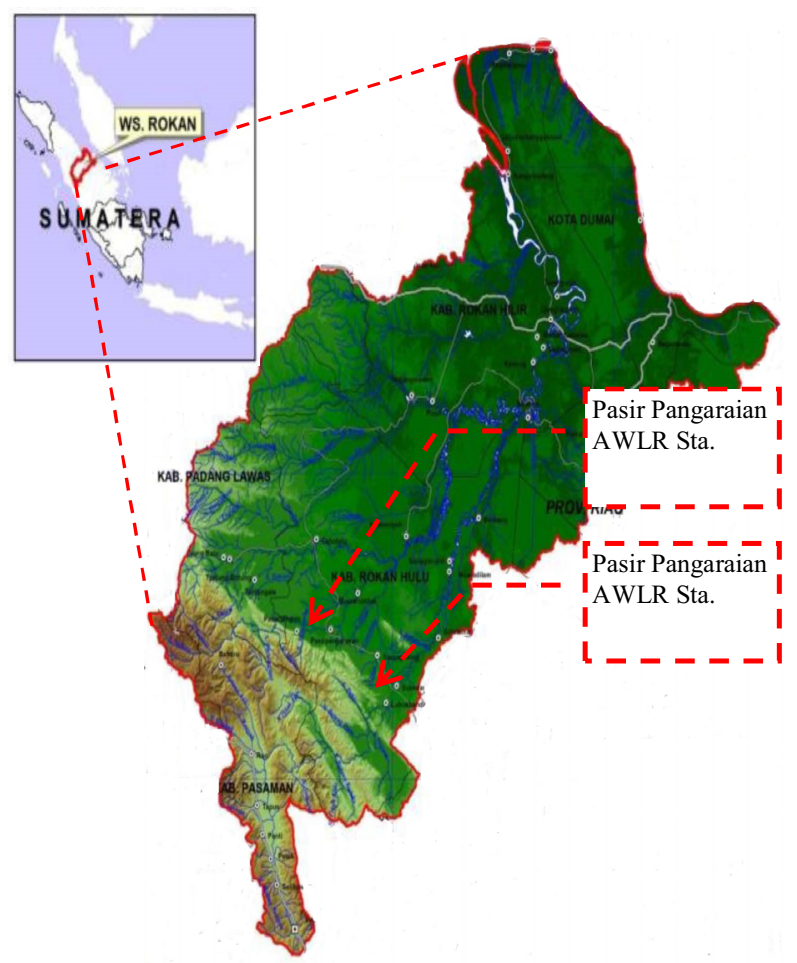

Fig. 1. Study area of this research

\subsection{Basic structure of IFAS}

IFAS which was developed by ICHARM) Japan, employs the Public Works Research Institute Distributed Hydrological Model (PDHM) as its runoff simulation model. The conceptual structure of PDHM is shown in Fig. 2. Surface flow, rapid subsurface flow, infiltration, slow subsurface flow and base flow are calculated by the equations from (1) to (5). In the process of river routing, the Kinematic Wave Model is employed. Also, IFAS can import some kinds of satellite-based rainfall data such as GSMaP and 3B42RT for insufficient ground observation area [2].
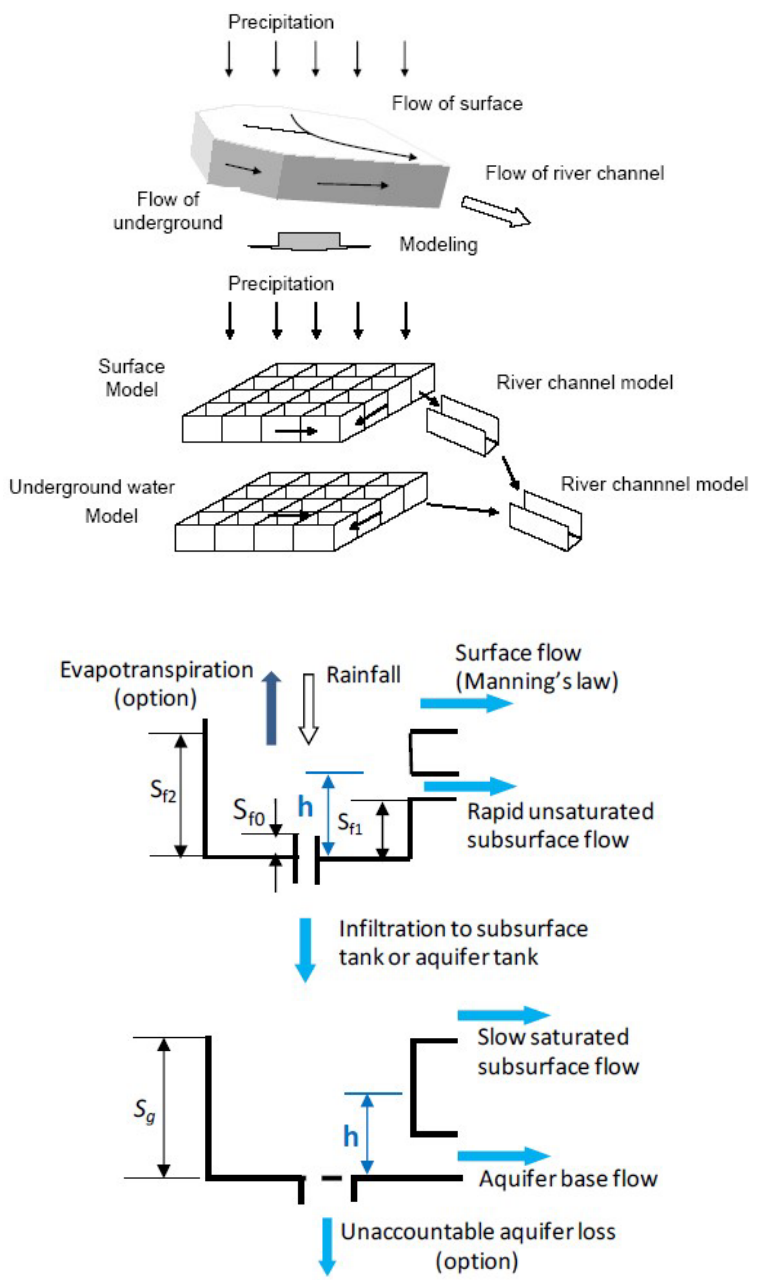

Fig. 2. Conceptual structure of IFAS

$$
\begin{gathered}
\mathrm{Q}_{\mathrm{d}}=\mathrm{L} \frac{1}{\mathrm{~N}}\left(\mathrm{~h}-\mathrm{S}_{\mathrm{f} 2}\right)^{\frac{5}{3}} \sqrt{\mathrm{i}} \\
\mathrm{Q}_{\mathrm{ri}}=\alpha_{\mathrm{n}} \mathrm{Af}_{\mathrm{o}} \frac{\left(\mathrm{h}-\mathrm{S}_{\mathrm{f} 1}\right)}{\mathrm{S}_{\mathrm{f} 2}-\mathrm{S}_{\mathrm{f} 1}} \\
\mathrm{Q}_{0}=\mathrm{Af}_{0} \frac{\left(\mathrm{h}-\mathrm{S}_{\mathrm{f} 0}\right)}{\mathrm{S}_{\mathrm{f} 2}-\mathrm{S}_{\mathrm{f} 0}} \\
\mathrm{Q}_{\mathrm{g} 1}=\mathrm{A}_{\mathrm{u}}^{2}\left(\mathrm{~h}-\mathrm{S}_{\mathrm{g}}\right)^{2} \mathrm{~A} \\
\mathrm{Q}_{\mathrm{g} 2}=\mathrm{A}_{\mathrm{g}} \mathrm{h} \mathrm{A}
\end{gathered}
$$

where $Q_{s f}:$ surface flow $\left(\mathrm{m}^{3} / \mathrm{s}\right), L$ : mesh length $(\mathrm{m}), N$ : manning's roughness coefficient $\left(\mathrm{m}^{-1 / 3} / \mathrm{s}\right), h$ : water height for the tank $(\mathrm{m}), S_{f 2}$ : height from which surface flow occurs (m), $i$ : slope with the adjacent cell, $Q_{r i}$ : rapid unsaturated subsurface flow $\left(\mathrm{m}^{3} / \mathrm{s}\right), A$ : mesh area $\left(\mathrm{m}^{2}\right)$, $S_{f 1}$ : height from which rapid unsaturated subsurface flow occurs (m) $Q_{0}$ : infiltration to aquifer tank $\left(\mathrm{m}^{3} / \mathrm{s}\right), S_{f 0}$ : height where ground infiltration occur $(\mathrm{m}), Q_{g 1}$ : slow saturated subsurface flow $\left(\mathrm{m}^{3} / \mathrm{s}\right), S_{g}$ : height from which slow saturated subsurface flow occurs (m), $Q_{g 2}$ : base flow $\left(\mathrm{m}^{3} / \mathrm{s}\right), \alpha_{n}, f_{0}, A_{u}, A_{g}$ : coefficients. 


\subsection{Data for hydrologic model setup}

The data used in the study consisted of satellite data and the discharge measured data. The discharge measurement data was needed for calibration process. The remote sensing data sets enabling the implementation and testing of a distributed hydrologic model in the Rokan waterhed include Digital Elevation Model (DEM), rainfall, land-use / land cover, and soil parameters.

\subsubsection{Digital Elevation Model (DEM)}

Digital Elevation Model (DEM) is determined from the Global Data which which can be downloaded from site (http://edcftp.cr.usgs.gov/pub/data/gtopo30/global/) directly from IFAS. Global data sets relevant to flood analysis which can be used to create run-off analysis model and estimates parameters for the river basin. The elevation within the catchment area can be determined and the model will then generate the catchment boundary. Fig. 3 shows the river basin and subcatchment area of AWLR Lubuk Bendahara in upper Rokan watershed.

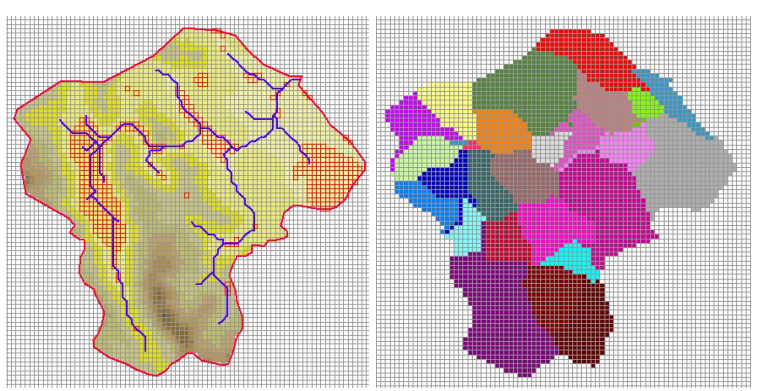

Fig. 3. (i) Lubuk Bendahara river basin, (ii) Sub catchment generates from IFAS.

\subsubsection{Rainfall input}

Two types of rainfall data are used as input data to the IFAS model which are ground and satellite-based rainfall data. IFAS can read rainfall point data (like rain gauges data) if saved in CSV format where location of the station and time of the measurements are specified. For the satellite rainfall data, GSMaP (Global Satellite Mapping of Precipitation) was was used in this study. GSMaP data can be downloaded directly from IFAS Rainfall Data Manager.

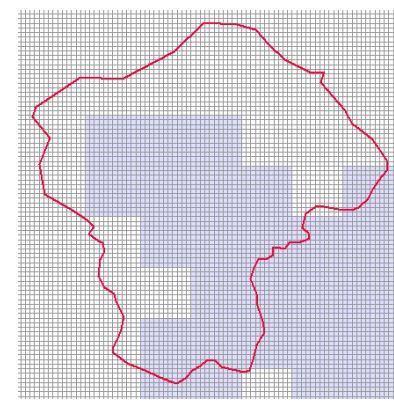

Fig. 4. GSMap rainfall data 2012
IFAS has a built-in GSMaP import function which uses the Microwave radiation device. Furthermore, 3B42RT is also one of the rainfall product provided by NASA (National Aeronautics and Space Administration, US) that can be downloaded and imported by IFAS through the Rainfall Data Manager. Fig. 4 shows the GSMaP rainfall data 2012 of catchment area of AWLR Lubuk Bendahara in upper Rokan watershed.

\subsubsection{Land-use and soil parameters}

Soil parameterse data is ulilized from United Nations Environment Programme (UNEP) GNV25 Soil Water which can be downloaded from site (http://www.grid.unep.ch/data/data.php). GNV25 data is the data of soil water holding capacity, which have been selected for commonly used for hydrological modeling. Fig. 5(i) shows the soil parameters data of river basin AWLR Lubuk Bendahara in upper Rokan watershed.

Land Use data is ulilized from GLCC (Global Land Cover Characterization) which which can be downloaded from site (http://edcftp.cr.usgs.gov/pub/data/glcc/globe/latlon/) directly from IFAS. This data is a database of characteristics of land created by the USGS, University of Nebraska-Lincoln (UNL), and the European Commission's Joint Research Centre (JRC) with a resolution of global $1 \mathrm{~km}$. Fig. 5(ii) shows the land-use data of river basin AWLR Lubuk Bendahara in upper Rokan watershed.
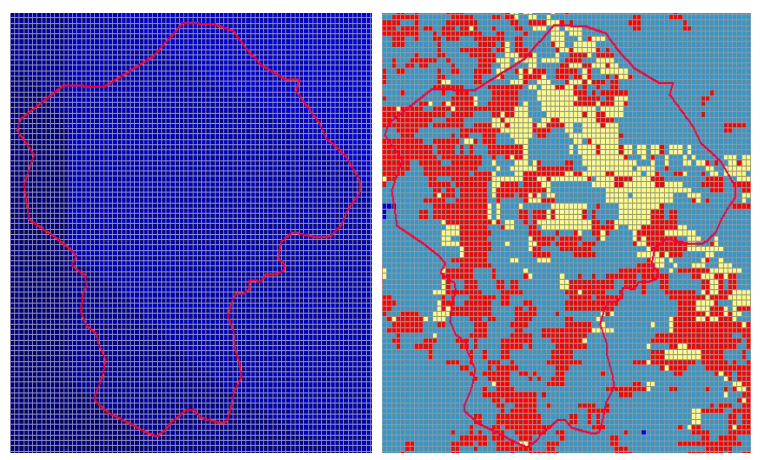

Fig. 5. (i) Soil data (UNEP) and (ii) land-use data (GLCC) of study area

\subsubsection{Model calibration and validation}

Model calibration is a process of optimizing or systematically adjusting the model parameter values to obtain a set of parameters that provide the best estimate of streamflow were observed. In other words, the process of optimizing the value of the parameter to improve the coherence between the hydrological response observed and simulated. In this research, the IFAS system has some parameters that can be calibrated using a reference of regional hydrological data were observed (measured data). There are eleven hydrological parameters are calibrated on this modeling. The sensitivity of these parameters on the response of hydrological model calibration phase has been examined in study area [11]. 
The performance of the IFAS model is evaluated by three indices like wave shape error, volume error and peak discharge error which are defined by the Japan Institute of Construction Engineering (JICE). The each and every indicator can be described as shown in the Table 1.

Table 1. Indicators for the error analysis of IFAS

\begin{tabular}{|c|c|c}
\hline Wave Shape Error & Volume Error & Peak Discharge Error \\
\hline$E_{w}=\frac{1}{n} \sum_{i=1}^{n}\left(\frac{Q_{O(i)}-Q_{C(i)}}{Q_{O(i)}}\right)^{2}$ & $E_{v}=\frac{\sum_{i=1}^{n} Q_{O(i)}-\sum_{i=1}^{n} Q_{C(i)}}{\sum_{i=1}^{n} Q_{O(i)}}$ & $E_{P}=\frac{Q_{O P}-Q_{C P}}{Q_{O P}}$ \\
\hline
\end{tabular}

where, $E, E_{W}, E_{v}$ and $E_{p}$ represent Error, Wave Shape Error, Volume Error and Peak Discharge Error respectively; $n$ : The number of calculating time; $Q_{O(i)}$ : Measured run-off at time I; $Q_{C(i)}$ : Calculated run-off at time I; $Q_{O P}$ : Calculated maximum run-off; $Q_{O P}$ : Measured maximum run-off.

\section{Results and discussions}

\subsection{Initial simulation}

At the beginning of the simulation, hydrological parameters used for the simulation was the default parameters specified by IFAS based on satellite data input. This simulation was carried out for a period of two weeks during flood event in 2012. The simulation results of this model is the form of discharge hydrograph along those period as shown in Fig 6. and Fig. 7 for Lubuk Bendahara and Pasir Pangarayan station respectively. Comparison between the simulation and measured hydrograph show the similar trend, but the magnitude is not acceptable.

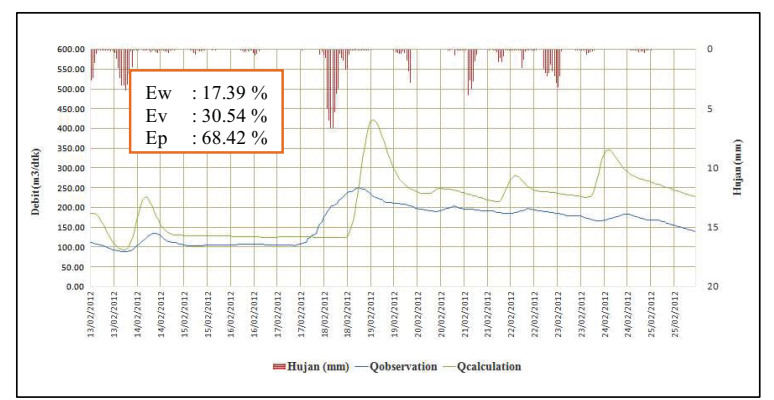

Fig. 6. Discharge hydrograph for initial simulation in Lubuk Bendahara station in 2012

As shown in Fig. 6, the peak of simulation discharge of Lubuk Bendahara sub-basin is still significantly under estimate compared with the measurement peak discharge. The magnitude of simulation peak discharge about $250 \mathrm{~m}^{3} / \mathrm{sec}$, while the measurement peak discharge about $420 \mathrm{~m}^{3} / \mathrm{sec}$. The value of wave shape error, volume error and peak discharge error are $17.39 \%$, $30.54 \%$ and $68.43 \%$ respectively. The peak of simulation discharge of Pasir Pangarayan sub-basin is quite close with the measurement peak discharge as shown in Fig.6.
The magnitude of simulation peak discharge about 250 $\mathrm{m}^{3} / \mathrm{sec}$, while the measurement peak discharge about 270 $\mathrm{m}^{3} / \mathrm{sec}$. The value of wave shape error, volume error and peak discharge error are $43.52 \%, 9.92 \%$ and $5.94 \%$ respectively. To improve the accuracy and the correlation, it is necessary to calibrate the hydrological parameters.

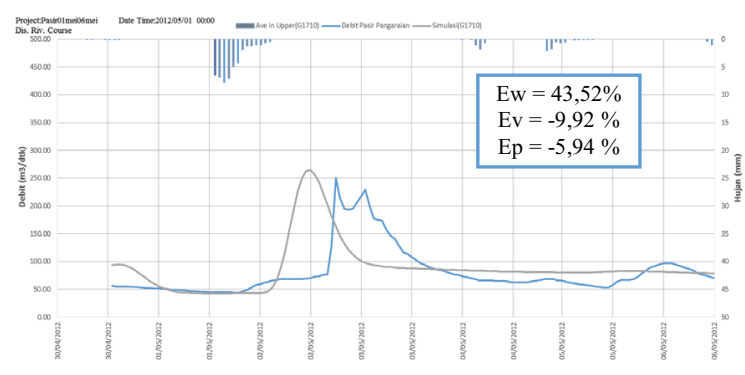

Fig. 7. Discharge hydrograph for initial simulation in Pasir Pangarayan station in 2012

\subsection{Model calibration}

Calibration process was done by trial on hydrological parameters so that the output discharge from the model as close as possible with measured discharge. After calibration process, the simulation hydrograph showed better corelation with measured hydrograph as shown in Fig. 8 and Fig. 9 for Lubuk Bendahara and Pasir Pangarayan sub-basin respectively. For Lubuk Bendahara sub-basin, the value of wave shape error, volume error and peak discharge error are $9.58 \%$, $17.28 \%$ and $10.81 \%$ respectively, and for Pasir Pangarayan sub-basin, the value of wave shape error, volume error and peak discharge error are 9.58\%, $17.28 \%$ and $10.81 \%$ respectively.

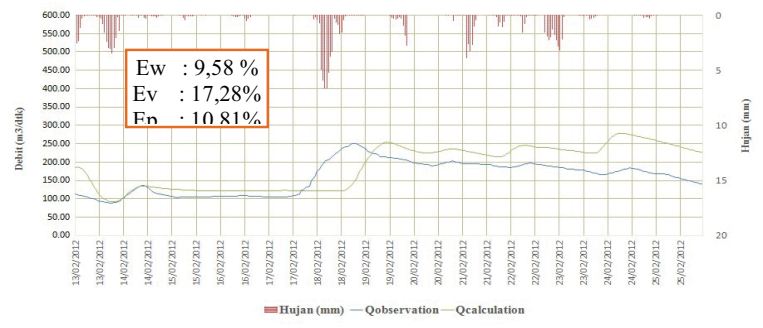

Fig. 8. Discharge hydrograph after calibration in Lubuk Bendahara station in 2012

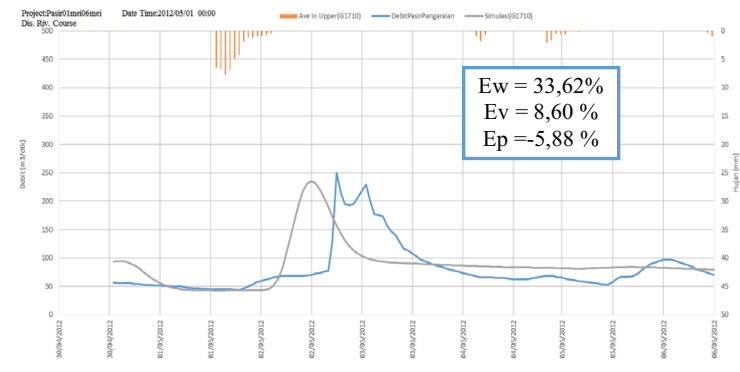

Fig. 9. Discharge hydrograph after calibration in Pasir Pangarayan station in 2012 
As shown in Fig. 8 and Fig. 9, the peak discharge generated from models already approaching the magnitude of the peak discharge measurement results in the field, with a peak discharge error (Ep) amounted to $10.81 \%$ and $5.88 \%$ for Lubuk Bendahara and Pasir Pangarayan sub-basin respectively.

\subsection{Flood event simulation}

After the model was calibrated, then it was used to simulate a flood event in Lubuk Bendahara village which was occured on February 15-17, 2013. The model was simulated using GSMap_NRT rainfal data on those period and the calibrated parameters. The simulation result shows that flood event was occured on February $15-17,2013$ as shown in Fig. 9. It means that the simulation result has a good correlation with the data from flood historical record in Rokan Hulu regency. The maximum discharge from the simulation on that flood event is about $760.57 \mathrm{~m}^{3} / \mathrm{sec}$. The measured peak discharge in the same time periode is $690.57 \mathrm{~m}^{3} / \mathrm{sec}$. It means that The flood discharge prediction show an acceptable error with the ground measurement data.

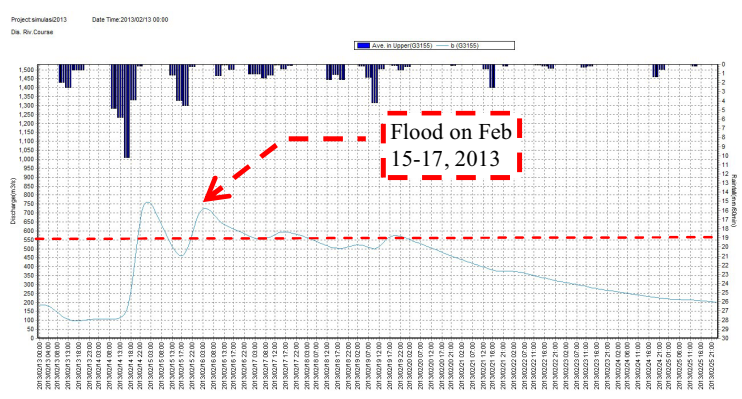

Fig. 10. Flood event in Lubuk Bendahara Sub-basin, Rokan Hulu regency on February 13-15, 2013

\section{Conclusions}

This study applied a method on hydrologic modeling using TRMM satellites data and IFAS tool for flood analysis. The results of this study show that the hydrologic modeling using satellite data can be used as an alternative for flood analysis in the area with limited ground data. The flood discharge prediction show an acceptable error with the ground measurement data. The wave shape error, the volume error, and the peak discharge error for Lubuk Bendahara station are 9.58\%, $17.28 \%$, and $10.81 \%$, and for Pasir Pangaraian station are $33.62 \%, 8,60 \%$ and $5,88 \%$ respectively

The author would like to thank the Directorate General of Higher Education (DIKTI) - Ministry of Research, Technology and Higher Education for its research grants program.

\section{References}

1. S. N. Jonkman and J. K. Vrijling, J. Flood Risk Manag., vol. 1, no. 1, pp. 43-56, (2008).

2. K. Fukami and Y. Shiraishi, Public Work (2009).

3. T. Sugiura, Proceedings of 7th ISE \& 8th HIC, Chile, pp. 1-6, (2009).

4. H. Wu, R. F. Adler, Y. Hong, Y. Tian, and F. Policelli, J. Hydrometeorol., vol. 13, no. 4, pp. 1268-1284, (2012).

5. A. Harris, S. Rahman, F. Hossain, L. Yarborough, A. C. Bagtzoglou, and G. Easson, ISSN 1424-8220, vol. 7, pp. 3416-3427, (2007).

6. I. Hafiz, N. D. M. Nor, L. M. Sidek, H. Basri, M. N. Hanapi, and L. Livia, IOP Conf. Ser. Earth Environ. Sci., vol. 16, p. 012128, (2013).

7. K. Fukami, S. Nabesaka, M. Miyamoto, and A. Sugiura, International Centre for Water Hazard and Risk Integrated Flood Analysis System (IFAS), pp. 1-15 (2009).

8. K. Fukami, International Centre for Water Hazard and Risk Integrated Flood Analysis System. (2009)

9. Y. Hendra, M. Fauzi, and S. Sutikno, Proceedings ACES (Annual Civil Engineering Seminar), vol. 1. pp. 61-72, 14-Dec-(2015).

10. S. Sutikno, M. Fauzi, and Hamiduddin, Seminar Nasional Teknik Sipil X-2014, 2014, p. 721 (2014).

11. S. Sutikno, M. Fauzi, and D. M. Mardhotillah, Pertemuan Ilmiah Tahunan (PIT) HATHI XXXI, 2014, pp. 481-492 (2014).

12. D. D. Chinh, N. Thi, T. Thuan, P. T. Van, T. N. Thanh, and V. Van, Proceedings of the 28th EnviroInfo 2014 Conference, Oldenburg, Germany, 2014, no. 1 (2014).

13. Bappeda, Dokumen Kajian Risiko Bencana Kabupaten Rokan Hulu, I. Pasir Pangarayan, (2015). 